\title{
Geomorphology Characteristic and Tectonic Response of the Meijiang Watershed in the Southern China Represented by Hypsometric Integral
}

\author{
Qinghua Gong ${ }^{1,2, *}$ Min Guo $^{3}$ Shuqing Fu ${ }^{1.2}$ \\ ${ }^{1}$ Guangzhou Institute of Geography, Guangzhou 510070, China \\ ${ }^{2}$ Guangdong Province Open Laboratory of Geographic Space information technology and application, \\ Guangzhou 510070, China \\ ${ }^{3}$ Guangdong Geological Survey, Guangzhou 510080, China
}

Received March 16, 2018

Accepted April 9, 2018

\begin{abstract}
MeiJiang river basin was selected as study area in this paper because it is a typical representative in the mountains of south China. Firstly, the study area was classified into several catchments in ARCGIS platform based on DEM data. Secondly, this paper withdraws the measuring indicators of the geomorphology and hypsometric integral from the basins. Then we study the information of geological structure and development of disaster situation. Finally, revealing the relationship between Hypsometric Integral and tectonic activity, lithological association and disaster intensity. It provides an important theory and method for studying geomorphic spatial pattern and characteristics of development as a whole. The result indicates that Hypsometric Integral has a spatial scale effect, geomorphology, lithology and disaster development can be simulated by small watersheds. For one thing, the studying area is in the mature phase, which is a high-incidence area with many kinds of mountain disasters; for another thing, the 1erosion resistance of biotite monzonitic granite is the most strongly. On the contrary, the sandstone, conglomerate, glutenite, siltstone, mudstone and limestone of it are weakly. At last, regional tectonic activity can be reflected by the Hypsometric Integral of big watershed units.
\end{abstract}

Key words: Hypsometric Integral, Southern China Mountain, geomorphology, tectonic, mountain disasters

\section{基于 DEM 的梅江流域面积高程积分及其地貌和构造意义}

\author{
宫清华 ${ }^{1,2}$ 郭敏 ${ }^{3 *}$ 付淑清 ${ }^{1,2}$ \\ 1.广州地理研究所, 广州 510070, 中国 \\ 2.广东省地理空间信息技术与应用公共实验室, 广州 510070, 中国 \\ 3.广东省地质调查院, 广州 510080 , 中国
}

摘要: 本文以广东省梅江流域为研究区域, 运用DEM为基础数据, 按照河流等级进行流域划分, 并计算各
流域单元的面积-高程积分值, 分析地质构造及灾害发育情况等资料, 揭示流域面积-高程积分值对构造活
动、岩性组合、及灾害发育强度的关系, 为从整体上研究地貌的空间格局及发育特征提供了重要理论与方

基金项目：国家自然科学基金（41671506); 广东省科技计划项目（2013B031500007，2014A020218013）。 作者简介: 宫清华, (1981-), 女, 内蒙古赤峰人, 博士, 副研究员, 主要从事环境地质方向研究, E-mail: gqh100608@163. com。通讯作者: 郭敏, (1982-), 男, 陕西咸阳人, 高级工程师, 主要从事地质矿产勘查 工作, E-mail: michae1031@163.com。

Copyright (C) 2018, the Authors. Published by Atlantis Press.

This is an open access article under the CC BY-NC license (http://creativecommons.org/licenses/by-nc/4.0/). 
法支撑。研究结果表明:面积-高程积分具有空间尺度效应, 小流域单元可较好模拟地貌、岩性和在山地灾害 发育特征, 且从地貌发育阶段上看, 研究区总体上处于地貌发育壮年期, 该区域也处于山地灾害高发区; 岩性组合对积分值得影响表现出黑云母二长花岗岩的抗侵蚀力最大, 砂岩、砾岩、砂砾岩以及粉砂岩、泥 岩、灰岩的抗侵蚀力较小; 大的流域单元积分值能较好反映区域构造活动性特征。

关键词: 面积-高程积分; 华南山区; 地貌; 构造; 山地灾害

\section{1.引言}

地形地貌是构造、气候和地表侵蚀相互作 用的结果, 是深部的固体地球物理构造和浅层 地表侵蚀内外营力综合作用的结果 ${ }^{[1-3]}$ 。因此, 地貌的形态特征是构造作用、流水侵蚀和岩性 基础等多要素综合作用的形态反映。近年来, 随着数字高程模型 (DEM) 和 GIS 技术的发展, 对地貌过程和构造活动等关系的研究也不断 深入。面积高程积分高程 - 面积积分 (Hypsometric Integral HI) 的分析方法由美 国地貌学家 Strahler 于 1952 年提出 ${ }^{[4]}$ 。是通 过统计流域地表的高程组合信息, 从而揭示流 域地貌形态与发育特征的重要指标 ${ }^{[5]}$, 是以二 维的面积-高程曲线来描述地表被侵蚀后的三 维体积残存率 ${ }^{[6]}$ 。目前在面积一高程分析方法 被广泛应用侵蚀地貌发育阶段定量研究中, 并 已基本形成理论方体系, 艾南山将面积一高程 分析法和信息墑原理相结合, 建立了侵蚀流域 系统的地貌信息熵理论 ${ }^{[7-8]}$ 。高程-面积积分除 被用于直接反映地貌形态特征外, 也被用于间 接反映区域流水地貌发育阶段、区域构造活动 性、灾害发育程度等方面。从地质学的角度, 信忠保 ${ }^{[9]}$, 施炜 ${ }^{[10]}$, 李利波 ${ }^{[11]}$ 等通过分析黄土 高原地区的地貌发育特征和构造的关系, 探讨 了黄土高原的地区面积高程积分值对构造活 动性额指示意义。赵洪壮 ${ }^{[6,12]}$ 探讨了面积高程 积分对再生造山带新构造活动的指示意义以 及其北麓流域的地貌发育过程; 姜鲁光 ${ }^{[13]}$ 、廖 义善 ${ }^{[14]}$ 等结合黄土高原土壤侵蚀的实际, 分析 了高程-面积分析与土壤侵蚀速率及侵蚀量的 关系。王晓朋 ${ }^{[15]}$ 、王钧 ${ }^{[16]}$ 等利用面积高程积分 值分析了流域发育阶段并以发育阶段为基础 判断了泥石流灾害的发育特征及危险性。

在以往的研究中, 一方面, 对于高程-面 积积分的应用研究多集中于构造、地貌、及灾 害评估的单一领域, 而高程一面积积分值实际 上是构造、岩性和地表侵蚀的综合反映, 在构 造和地貌研究中, 理应充分考虑地表侵蚀和岩 性特征的影响。另一方面, 目前地貌及构造研 究主要集中在黄土高原及青藏高原征地区, 而 对于华南地区的研究较少, 尤其是应用高程面积积分研究华南地区的地貌地质特征的研 究不多见, 而华南沿海地区, 是构造活动强烈
地区, 且因高温多雨的气候条件, 使得该区域 风化侵蚀较为强烈, 形成了华南独特的地貌特 征。本文根据华南地区地貌特征, 选取广东省 梅州市为案例区域, 以流域划分为基础, 从面 积高程积分值分析入手, 研究华南丘陵山区地 貌空间分异格局, 确定流域所处的发育阶段状 态, 并结合构造线、灾害发生情况及地质岩性 情况揭示面积高程积分值对构造活动性、岩性 特征及地质灾害发育程度方面的指示意义。

\section{2.研究区概况}

梅江流域位于广东省东北部, 面积 15876. $05 \mathrm{~km}^{2}$, 地势起伏较大, 形成了以山地 丘陵为主, 山谷相间的地貌格局。海拔 $100 \mathrm{~m}$ 以下的平原、阶地、台地占土地面积 $16.54 \%$, 100-400m 的丘陵占 $54.36 \%, 400-800$ 米的低 山占 $20.13 \%, 800-1000$ 米以上中山占 3.21 $\%$ 。三列东北-西南走向的山系有: 罗浮山、 莲花山、风凰山; 三列西北-东南或近乎南北 向的山地有: 七目嶂山地、铁山嶂山地、蕉平 山地, 构成梅州的地形格局 (图 1)。中部由 梅江河及其支流沿线冲积盆地和谷地组成; 东 南部山高坡陡, 河谷深切, 地形反差大; 西北 低山-丘陵区, 区内陵谷相间, 山势迤通起伏, 地形高差一般小于 $500 \mathrm{~m}$ 。

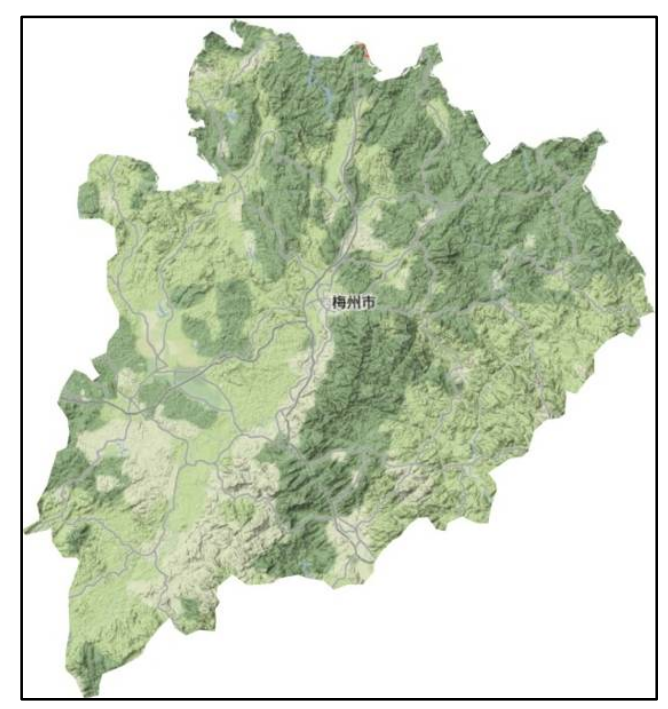

图 1 梅州市地貌格局图

Fig1. Geomorphology map of Meizhou city 
研究区内出露的地层由老至新有震旦系, 寒武系、泥盆系、石炭系、二叠系, 三叠系、 侏罗系、白严系, 古近系和第四系地层, 具有 西北老东南新的分布特点 (图2)。

研究区在大地构造上属华南准地台。构造 形态以北东向为主, 北西向次之, 南北向再次。 区内构造活动复杂, 经历了地槽、准地台和活 动大陆边缘三个发展阶段, 其最重要的构造线 为自南西向北东横穿梅州市的北东向莲花山 断裂带, 总体呈 $N E 45^{\circ}$ 展布, 主要由两条相间
约 $50 \mathrm{~km}$ 的大致平行的断裂束 (F1、F2) 及夹持 于其间的一系列断裂带组成。另外还有紫金博罗大断裂 $\mathrm{F} 6$, 河源深断裂 $\mathrm{F} 7$ 等; 北西向主要 有永和圩断裂 $\mathrm{F} 15$ 、神光山断裂 $\mathrm{F} 14$ 、石正圩断 裂F13、明山嶂断裂F12、帽山断裂F3、清泉溪 断裂F5、下桃子㟦断裂F4等; 近南北向构造线 位于研究区北部, 最近的研究表明在伸展与挤 压作用下，广泛发育滑脱构造，有佛子高断裂 F9、彭坑口断裂F10、北北东向韩江断裂F11。

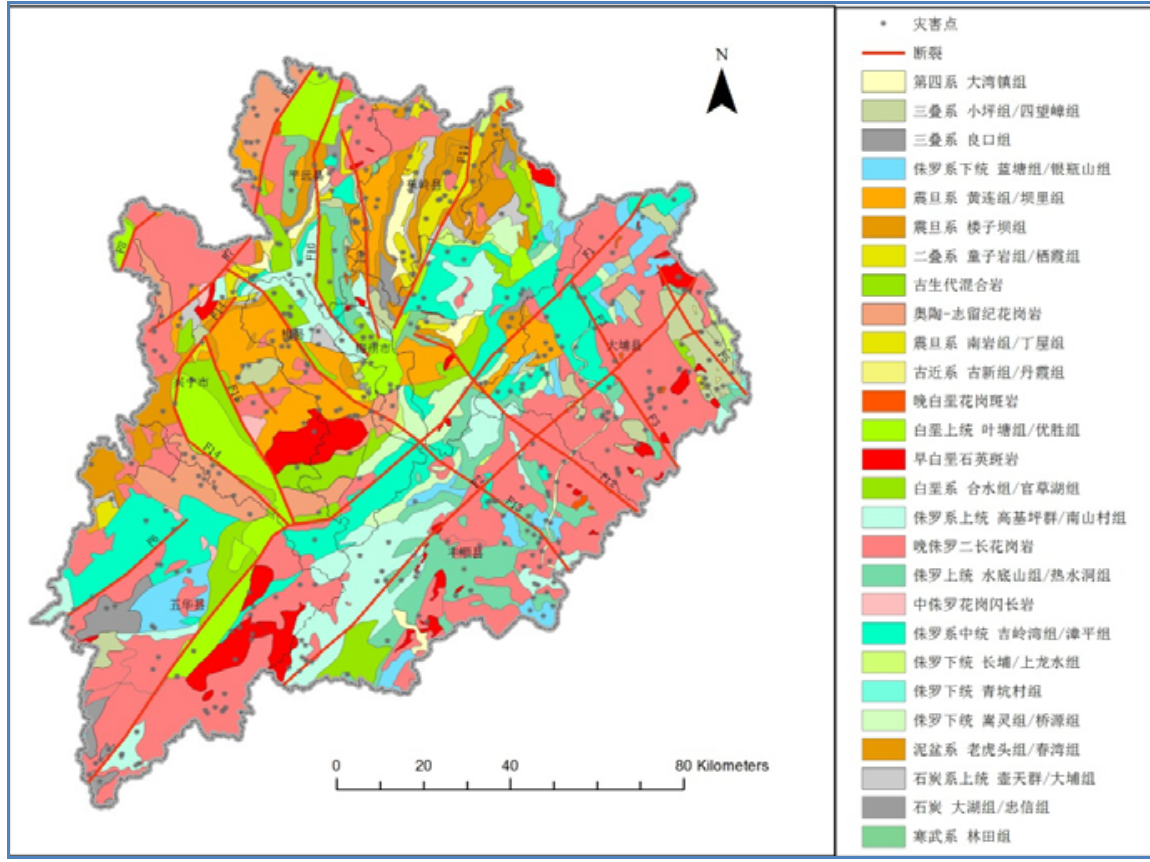

图 2 梅州市地质构造简图

Fig2. The simplified geological and structural map of Meizhou city

\section{3.数据和方法}

\section{1数据来源}

本文以 $1: 25$ 万地形图为基础资料，通过 ARCGIS9. 3 的 DEM 建模功能, 建立研究区 DEM 模型, 并以 DEM 数据为基础资料,在 ARCGIS9. 3 的水文分析模块及空间分析模块支撑下提取 出流域及各种常规定量化参数及高程-面积积 分值。并结合地质构造资料，历史灾情资料、 对面积一高程积分值对地貌发育阶段及构造活 动性的指示意义进行研究。以上各种数据资料 经过空间校正配准、投影变换，转换到统一的 WGS-84 坐标系下。

\section{2 分析方法}

\subsection{1流域的分割和提取}

流域划分是基于 DEM，应用水文学 D8 方 法进行水文因子的计算, 以 ARCGIS9. 3 为平台
实现的。整个计算过程分以下几个步骤：第一 步利用地形图生成 DEM 数据; 第二步进行 DEM 水流方向矩阵的计算, 查找和充填洼地, 生成 无洼地 DEM 数据; 第三步从无洼地 DEM 数据求 得各像元的流向和汇流量; 第四步是流域河网 的提取。在 ArcGIS9. 3 水文分析模块中借助 DEM 自动完成流域河网的提取。经过对不同累 积流量提取的河网进行对比，提取的水系与实 际水系最为接近时, 划分出来的小流域流域最 为理想。第五步, 确定小流域的出水口汇水点 位置, 所谓汇水点整个流域内内流水以及沉积 物最终集中的地区。汇水点也是流域的侵蚀基 准面, 在此基础上, 利用 ArcGIS 水文分析模 块。划分结果如图 3 所示。

\subsection{2高程-面积积分原理}

高程-面积分析法是定量化分析地貌发育 过程的方法, 该方法主要选取能反映地貌系统 总体演化特征的流域面积和流域的相对高度 为指标。高程-面积积分值的通常计算方法 是：假设流域内第 $i$ 条等高线以上面积为 $a_{i}$, 


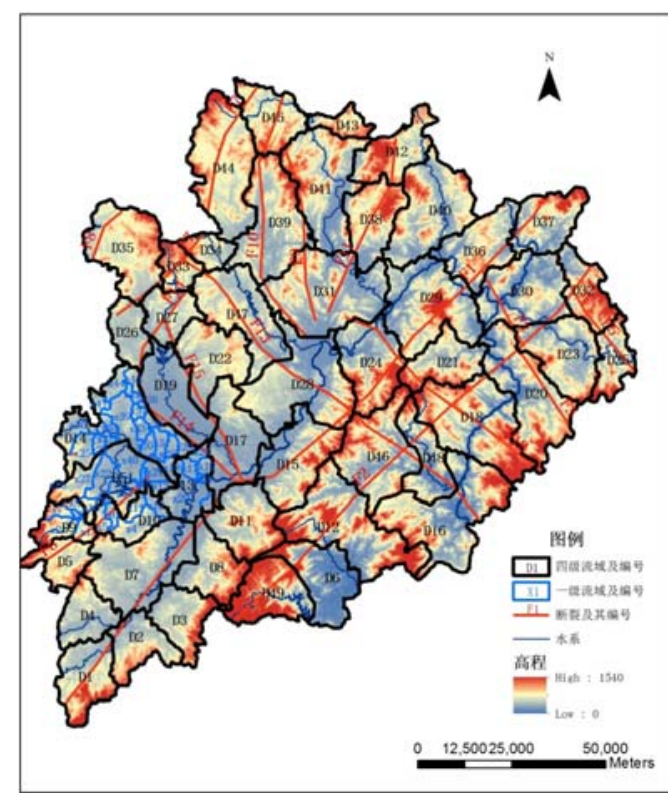

图 3 梅州市四级流域和部分一级流域分布图

Fig3. The fourth order basins and some of the first order basins in the study area

流域总面积为 $\mathrm{A}$, 该等高线与流域最低点的高 差为 $h_{i}$, 流域内最大相对高差为 $\mathrm{H}$ 。以为 $X_{i}=a_{i} / A$ 为横坐标, 以 $Y_{i}=h_{i} / H$ 为纵坐标, 根据得到的 一系列 $(\mathrm{x}, \mathrm{y})$ 值, 绘制的曲线即为面积-高程曲 线, 曲线与坐标轴之间的面积即为高程-面积

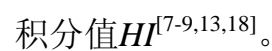

高程-面积积分值的具体意义是以二维的 面积一高程曲线来描述地表被侵蚀后的三维体 积残存率 ${ }^{[6]}$, 是流域内未被侵蚀掉的岩土体体 积被侵蚀之前总物质体积的比。

\section{$H I=V_{1} / V$}

式中 $V_{1}$ 为流域在地表面所确定的不规则 曲面与其在流域高程最小值所在的水平面上 的水平投影面之间所夹的体积, 即流域未被侵 蚀掉的物质体积; $V$ 为流域未发生侵蚀时的原 始体积 ${ }^{[19-20]}$ 。高程-面积积分除被用于直接反 映地貌形态特征外, 也可作为反映区域构造活 动性、灾害敏感性等方面的指标。

\subsection{3高程-面积积分计算}

通过对 DEM 进行高程分类, 统计出不同高 程以上的流域面积, 并借助 MATLAB 工具中的 曲线拟合模型对面积 - 高程函数进行拟合, 再 利用得到的拟合函数计算高程-面积积分是当 前广泛应用的方法 ${ }^{[5-6,9-10]}$ 。这种方法需要对各 对不同高程分类方法做不断尝试, 选择适合的 分类方法后进行统计和模拟, 计算过程较为繁 琐。ARCGIS 三维空间分析技术的发展为高程面积积分计算提供了崭新的途径, 面积一高程 积分的物理意义是计算被侵蚀后的三维体积
残存率, 借助 ArcGIS9. 3 软件平台中 ArcToolbox 中的 SurfaceVolume 可以统计残 存曲面 (DEM 曲面) 和未发生侵蚀前的体积, 并可运用其地图代数功能完成面积 - 高程积分 的计算。本文在 ArcGIS9. 3 支持中, 将梅州市 流域划分结果统计出每个流域的面积 A, 并将 小流域划分结果与梅州市 DEM 相叠加, 用区域 统计功能 (Zonal statistical) 统计出每个 流域单元内的最大高程、最小高程和最大高程 差。然后利用 SurfaceVolume 模块分别计算由 地形曲面和最低高程水平面所组成的 V1, 即 流域残存下来未被侵蚀掉的物质体积; 用最大 高程差和流域面积统计每个流域未发生侵蚀 时的原始体积 $\mathrm{V}$ 。利用 Zonal statistical 统 计的数据都以 Raster 格式存储, 用栅格计算 器 (raster caculator) 计算出每个流域单元 的高程-面积积分值 $H I$ 。

\subsection{4面积高程积分的尺度效应}

国内外相关研究表明, 面积高程积分可以 反映地貌的发育阶段、流域地貌面受侵蚀的程 度、山地灾害影响因素、构造活动性等特征 [21-24]。但因高程-面积积分值也具有面积依赖 和空间依赖等特性, 在研究过程中, 应该结合 研究目的和研究区地质地貌的实际情况进行 分析尺度的合理选择。本文研究目的通过面积 高程积分的计算, 反映梅州地区的地貌格局、 山地灾害发育程度及构造活动性等地质地貌 特征, 为确定研究区 HI对的尺度效应, 利用GIS 水文分析功能, 划分研究区河流等级, 划分不 同等级的流域, 并分别计算各级别流域对应的 $H I$ 值。并利用不同等级尺度的流域计算结果与 地质资料和灾害资料做叠加分后进行观察分 析。结果表明: 随着流域等级 (按照Strahler 河流等级划分法) 的增高和面积的增大, $H I$ 值随之下降, 且地貌、岩性和地表灾害侵蚀作 用主要受控于小流域, 经对比研究发现, 面积 $50 \mathrm{~km}^{2}$ 以下的一级流域计算所得的 $H I$ 值空间分 布与地层岩性、地貌类型等分布存在空间相对 一致性趋势。而随着流域单元面积的增大, $H I$ 值与地貌、岩性和灾害的相关性逐渐减小, $H I$ 空间分布趋势与区域构造特征空间相关性逐 渐增强, 当流域等级为四级, 流域单元面积为 $200-500 \mathrm{~km}^{2}$ 时, $H I$ 的结果较符合区域构造活动 特征。

因此, 本研究将一级小流域单元的 $H I$ 值 作为反映地貌特征、岩性组合和、灾害侵蚀程 度的指标, 将四级流域单元作为反映构造活动 的指标。梅江流域各四级流域及部分一级流域 的最低高程、最高高程、相对高差、流域面积 及面积-高程积分值如表 1 、表 2 。 
表 1 四级流域的最低高程、最高高程、相对高度、流域面积及 HI

Tab1. The HI value of the fourth order basins

\begin{tabular}{|c|c|c|c|c|c|c|c|c|c|c|c|}
\hline $\begin{array}{l}\text { 流域 } \\
\text { 编号 }\end{array}$ & $\begin{array}{c}\text { 最大高程 } \\
\text { (m) }\end{array}$ & $\begin{array}{c}\text { 最小高程 } \\
\text { (m) }\end{array}$ & $\begin{array}{c}\text { 最大高差 } \\
\text { (m) }\end{array}$ & $\begin{array}{c}\text { 流域面积 } \\
\left(\mathrm{km}^{2}\right)\end{array}$ & $H I$ & $\begin{array}{l}\text { 流域 } \\
\text { 编号 }\end{array}$ & $\begin{array}{c}\text { 最大高程 } \\
\text { (m) }\end{array}$ & $\begin{array}{c}\text { 最小高程 } \\
\text { (m) }\end{array}$ & $\begin{array}{c}\text { 最大高差 } \\
\text { (m) }\end{array}$ & $\begin{array}{l}\text { 流域面 } \\
\text { 积 }\left(\mathrm{km}^{2}\right)\end{array}$ & $H I$ \\
\hline D1 & 1076 & 150 & 926 & 264. 16 & 0.22 & D26 & 550 & 150 & 400 & 151.64 & 0.19 \\
\hline D2 & 737 & 150 & 587 & 212.43 & 0.28 & $\mathrm{D} 27$ & 653 & 150 & 503 & 168.34 & $=0.20$ \\
\hline D3 & 1189 & 150 & 1039 & 221.5 & 0.20 & $\mathrm{D} 28$ & 983 & 100 & 883 & 547.94 & 0.18 \\
\hline D4 & 897 & 105 & 792 & 196. 24 & 0.19 & D29 & 1244 & 50 & 1194 & 483. 12 & 0.19 \\
\hline D5 & 1139 & 188 & 951 & 158. 08 & 0.25 & D30 & 709 & 50 & 659 & 389.57 & 0.26 \\
\hline D6 & 1268 & 50 & 1218 & 305.81 & 0.26 & D31 & 696 & 0 & 696 & 553.46 & 0.34 \\
\hline D7 & 875 & 150 & 725 & 476.52 & 0.12 & D32 & 984 & 100 & 884 & 199. 33 & 0.34 \\
\hline D8 & 1144 & 150 & 994 & 247.33 & 0.22 & D33 & 861 & 200 & 661 & 114.19 & 0.37 \\
\hline D9 & 1268 & 200 & 1068 & 140.55 & 0.22 & D34 & 887 & 200 & 687 & 98.16 & 0.21 \\
\hline D10 & 658 & 150 & 508 & 172. 33 & 0.25 & D35 & 1000 & 200 & 800 & 382.76 & 0.20 \\
\hline D11 & 927 & 100 & 827 & 294.98 & 0.26 & D36 & 692 & 50 & 642 & 294.52 & 0.35 \\
\hline D12 & 1246 & 50 & 1196 & 549.4 & 0.30 & D37 & 1051 & 50 & 1001 & 250.56 & 0.28 \\
\hline D13 & 315 & 100 & 215 & 190.27 & 0.26 & D38 & 1080 & 100 & 980 & 266.22 & 0.30 \\
\hline D14 & 698 & 150 & 548 & 509.71 & 0.19 & D39 & 1088 & 100 & 988 & 447.74 & 0.20 \\
\hline D15 & 1003 & 1 & 1002 & 373.39 & 0.29 & $\mathrm{D} 40$ & 1106 & 52.61 & 1053 & 448.43 & 0.23 \\
\hline D16 & 1452 & 0 & 1452 & 564.11 & 0.22 & D41 & 1136 & 100 & 1036 & 474.94 & 0.20 \\
\hline D17 & 517 & 0 & 517 & 327.18 & 0.34 & $\mathrm{D} 42$ & 1124 & 150 & 974 & 243.47 & 0.27 \\
\hline D18 & 1540 & 50 & 1490 & 526.81 & 0.24 & $\mathrm{D} 43$ & 928 & 150 & 778 & 85.49 & 0.37 \\
\hline D19 & 395 & 100 & 295 & 306.53 & 0.17 & D44 & 1447 & 150 & 1297 & 493.78 & 0.18 \\
\hline D20 & 1110 & 0 & 1110 & 464.74 & 0.29 & $\mathrm{D} 45$ & 836 & 150 & 686 & 234.48 & 0.33 \\
\hline D21 & 1334 & 50 & 1284 & 234.82 & 0.26 & $\mathrm{D} 46$ & 1452 & 0 & 1452 & 419.57 & 0.22 \\
\hline D22 & 768 & 150 & 618 & 305.78 & 0.23 & $\mathrm{D} 47$ & 983 & 100 & 883 & 391.69 & 0.18 \\
\hline D23 & 1035 & 100 & 935 & 336.72 & 0.22 & $\mathrm{D} 48$ & 1452 & 0 & 1452 & 222.83 & 0.22 \\
\hline D24 & 1272 & 100 & 1172 & 333.86 & 0.20 & $\mathrm{D} 49$ & 1268 & 50 & 1218 & 289.86 & 0.26 \\
\hline D25 & 1229 & 100 & 1129 & 163.3 & 0.25 & D50 & 698 & 150 & 548 & 341.28 & 0.19 \\
\hline
\end{tabular}

\section{4. 结果分析}

4.1面积-高程积分值的空间分布格局

梅江流域地区 $H I$ 值空间分布存在显著的 区域差异。 $H I$ 的低值区主要分布在中部梅江 河及其支流盆谷区, 由梅江河及其支流沿线冲 积盆地和谷地组成, 如宁江河谷盆地、程江河 谷盆地平原等地区。 $H I$ 的高值区主要分布在 于中低山和低山丘陵区, 包括西北-东南或近 乎南北向的山地有地区: 有七目嶂山地、铁山 嶂山地、蕉平山地和东北-西南走向的山系有: 罗浮山系、莲花山系、风凰山系。面积高程积 分较低的地区集中分布于区域东南部, 东南部 山高坡陡，河谷深切，地形反差大。
4.2面积-高程积分值反映的地貌发育的阶段性

流域的发育是地面在各种内、外营力作用 影响下对地面不断再塑造的结果, 流域变化的 呈现一定的模式与规律。在华南小流域区域, 松散且厚红层风化壳的覆盖了大部分的地表, 独特的气候条件造成侵蚀方式基本上以流水 侵蚀为主。在不考虑构造作用时, 流域的发育 过程就是不断风化侵蚀的过程, 在流域上游, 有效能量很大, 流域地貌处于河网密度小, 地 面比较完整, 河流深切侵蚀决裂, 河谷呈 V 形, 随着流域的发育, 流域地貌越趋于幼年晚期, 深切下蚀作用逐渐减弱, 侧蚀作用逐渐加强, 地面分割得越来越破碎, 地形势起伏度最大, 地貌发育初期, 岩石残存率较高, $H I$ 值也较 高; 在流域中游, 有效能量逐渐减小, 河流以 
表 2 部分一级流域的最低高程、最高高程、相对高度、流域面积及 HI

Tab 2. The minimum altitude, maximum altitude, relative height, area and HI value of the first order basins

\begin{tabular}{|c|c|c|c|c|c|c|c|c|c|c|c|}
\hline $\begin{array}{l}\text { 流域 } \\
\text { 编号 }\end{array}$ & $\begin{array}{l}\text { 最小高 } \\
\text { 程 }(\mathrm{m})\end{array}$ & $\begin{array}{l}\text { 最大高 } \\
\text { 程 }(\mathrm{m})\end{array}$ & $\begin{array}{l}\text { 最大高 } \\
\text { 差 (m) }\end{array}$ & $\begin{array}{c}\text { 流域面 } \\
\text { 积 (km2) }\end{array}$ & $H I$ & $\begin{array}{c}\text { 流域编 } \\
\text { 号 }\end{array}$ & $\begin{array}{l}\text { 最大高 } \\
\text { 程 (m) }\end{array}$ & $\begin{array}{l}\text { 最小高 } \\
\text { 程 (m) }\end{array}$ & $\begin{array}{l}\text { 最大高 } \\
\text { 差 (m) }\end{array}$ & $\begin{array}{c}\text { 流域面 } \\
\text { 积 (km2) }\end{array}$ & $H I$ \\
\hline X1 & 29.48 & 633 & 190 & 443 & 0.352 & X23 & 18.82 & 273 & 102 & 171 & 0.438 \\
\hline X2 & 36.00 & 1279 & 205 & 1074 & 0.250 & X24 & 14.95 & 422 & 123 & 299 & 0.280 \\
\hline X3 & 4. 44 & 429 & 193 & 236 & 0.399 & X25 & 41.27 & 693 & 124 & 569 & 0.273 \\
\hline X4 & 42. 10 & 637 & 114 & 523 & 0.322 & X26 & 2. 42 & 660 & 134 & 526 & 0.373 \\
\hline X5 & 26.35 & 658 & 172 & 486 & 0.337 & X27 & 46.52 & 660 & 134 & 526 & 0.373 \\
\hline X6 & 18.11 & 554 & 167 & 387 & 0.314 & X28 & 17.50 & 307 & 120 & 187 & 0.321 \\
\hline X7 & 23.27 & 764 & 215 & 549 & 0.423 & X29 & 20. 32 & 259 & 126 & 133 & 0.444 \\
\hline X8 & 15. 32 & 642 & 208 & 434 & 0.452 & X30 & 20.63 & 287 & 111 & 176 & 0.287 \\
\hline X9 & 4. 11 & 375 & 151 & 224 & 0.334 & X31 & 26. 09 & 289 & 111 & 178 & 0.385 \\
\hline X10 & 22.84 & 627 & 161 & 466 & 0.327 & X32 & 16.56 & 401 & 116 & 285 & 0.230 \\
\hline X11 & 23.27 & 481 & 123 & 358 & 0.458 & X33 & 18. 20 & 333 & 125 & 208 & 0.338 \\
\hline X12 & 25.20 & 253 & 113 & 140 & 0.440 & X34 & 16.84 & 476 & 118 & 358 & 0.237 \\
\hline X13 & 17.86 & 286 & 106 & 180 & 0.311 & X35 & 19.48 & 351 & 141 & 210 & 0.293 \\
\hline X14 & 48.24 & 586 & 151 & 435 & 0.225 & X36 & 45.63 & 714 & 124 & 590 & 0.161 \\
\hline X15 & 4. 96 & 189 & 93 & 96 & 0.308 & X37 & 13. 02 & 364 & 143 & 221 & 0.381 \\
\hline X16 & 9.10 & 245 & 115 & 130 & 0.318 & X38 & 3.53 & 266 & 148 & 118 & 0.480 \\
\hline X17 & 19.43 & 254 & 93 & 161 & 0.424 & X39 & 47.50 & 506 & 116 & 390 & 0.233 \\
\hline X18 & 21. 12 & 280 & 104 & 176 & 0.305 & X40 & 43.50 & 316 & 113 & 203 & 0.202 \\
\hline X19 & 17.78 & 275 & 93 & 182 & 0.427 & X41 & 21.03 & 438 & 140 & 298 & 0.301 \\
\hline X20 & 46.00 & 306 & 104 & 202 & 0.281 & X42 & 12.69 & 319 & 160 & 159 & 0.376 \\
\hline X21 & 27.60 & 258 & 102 & 156 & 0.175 & X43 & 21.33 & 339 & 145 & 194 & 0.483 \\
\hline X22 & 41.25 & 439 & 113 & 326 & 0.209 & X44 & 38.07 & 384 & 149 & 235 & 0.302 \\
\hline
\end{tabular}

侧蚀、重力作用和坡面冲刷为主，地貌形态上 谷坡变得缓平, 山脊变得浑圆, 地面由原来的 峭峰深谷, 变成低丘宽谷, 侵蚀能力也逐渐变 低, 水系发展稳定, 流域处于壮年期, HI 值 降低。当流域地貌处于侵蚀发育阶段的老年期 时, 也就是河流下游平原地区, 河流作用主要
为侧蚀和堆积, 下蚀作用已经很微弱, 地势起 伏微缓, 形成宽广的谷底平原, $H I$ 值最低。 可根据面积高程积分值将地貌发育分为三个 阶段：幼年阶段 (大于 0.6 ) ; 壮年阶段 (大于 0.35 且小于 0.6 ) ; 老年阶段 (小于 0.35$)^{[9]}$ 。

表 3 一级小流域发育阶段汇总表

Tab3. Summary table of first order basins

\begin{tabular}{|c|c|c|c|c|c|}
\hline \multirow{2}{*}{ 发育阶段 } & 所占面积 & \multirow{2}{*}{ 所占面积比例 } & \multirow{2}{*}{ 小流域数量 } & \multirow{2}{*}{ 流域数量所占比例 } & \multirow{2}{*}{$\begin{array}{c}\text { 小流域平均面积 } \\
\left(\mathrm{km}^{2}\right)\end{array}$} \\
\hline & $\left(\mathrm{km}^{2}\right)$ & & & & \\
\hline 幼年期 & 3674 & 23.14 & 196 & 26.52 & 18.71 \\
\hline 壮年期 & 10560 & 66.52 & 480 & 64.95 & 22 \\
\hline 老年期 & 1641 & 10.34 & 63 & 8.53 & 26.04 \\
\hline 合计 & 15875 & 100 & 739 & 100 & \\
\hline
\end{tabular}

根据计算结果梅州一级小流域丘陵区处 于不同地貌发育阶段的面积比重基本稳定, 处 于幼年、壮年和老年期面积分别大约占总面的
$23.14 \% 、 66.52 \%$ 和 $10.34 \%$, 整体处于壮年期, 并且从幼年期到壮年期, 流域的平均面积呈增 大的趋势（表 3 ）。这是因为研究区该流域地 形格局总体上北东向展布, 山高坡陡, 河谷深 
切，以遭受流水切割、搬运和综合外力风化、 剥蚀地质作用为主。

\section{3面积-高程积分反映的山地灾害发育程度}

根据以上判断，该区域整体出去地貌发育 壮年期, 以侵蚀作用为主, 加之处于我国南方 暴雨多发区，频发的滑坡灾害是地貌发育所处 阶段的自然表现。但从发育的各个阶段统计来 看整体灾害的发育密度在壮年期和幼年期较 为发育, 而壮年期相对密度较小，而从地貌特 征上来看, 由幼年期到壮年期地貌形态从山高 坡陡逐渐变为地势平缓, 从理论上说明在幼年 期到老年期, 灾害点的发育情况应呈现逐渐减 弱的趋势, 这两者之间存在矛盾。

从宏观观察结果判断, 诱发滑坡的另外一 个不可忽视因素为人类工程活动。在山区, 人 类活动的主要空间为沟谷盆地和坡脚地带, 向 坡地拓展空间的切坡活动会引发滑坡灾害的 发生, 根据流域发育阶段理论, 这些区域处于 地貌发育的晚年期, 因此也可以得出在山区, 人类工程活动影响也是引发滑坡的另一个重 要因素。

\section{4面积-高程积分值所反映的构造活动性}

本区北东向、北西向、南北向构造穿过梅 州市一级流域及部分面积较大的四级流域 (见 图 3), 其面积适合用来解析各个断裂内部活 动性的差异。紫金-博罗大断裂（F6）位于研 究区南西部, 自南西向北东穿过了 D5、D9、 D10、D50, HI 依次为 $0.254 、 0.217 、 0.251$ 、 0.186。可以看出该断裂活动性自南西向北东 逐渐减弱。

河源深断裂（F7）总体呈 “S” 型展布, 自南西向北东穿过了 D26、D35、D33、D34、 $\mathrm{D} 44, H I$ 依次为 $0.194 、 0.198 、 0.367 、 0.208$ 、 0.177 。可以看出该断裂中部活动性较强, 向 两端一次减弱, 这是由于 D33 单元处于北东向 断裂内与北西向 F15 断层相交处。

南北向断裂带主要包括佛子高断裂和彭 坑口断裂 (F9、F10), 为压扭性断裂, 自南向 北呈 “S” 形展布, 穿过了 D31、D39、D41、 $\mathrm{D} 45, H I$ 依次为 $0.343 、 0.204 、 0.203 、 0.331$ 。 可以看出断裂带南部 D31 单元内, 由于上述两 条断裂和北北东向韩江断裂 (F11) 以及北西 向明山嶂断裂共同交汇于此, 构造活动性非常 强。

莲花山断裂带 (F1、F2) 总体呈 $\mathrm{NE} 45^{\circ}$ 展布, 主要由两条相间约 $50 \mathrm{~km}$ 的大致平行的 断裂束（F1、F2）及夹持于其间的一系列断裂 带组成。自南西向北东穿过了 D1、D2、D3、 D8、D49、D11、D6、D15、D12、D46、D24、D18、 D21、D20、D30、D36、D37、D32，HI 依次为
$0.225 、 0.276 、 0.209 、 0.220 、 0.258 、 0.258$ 、 $0.258 、 0.293 、 0.299 、 0.221 、 0.202 、 0.236$ 、 $0.263 、 0.287 、 0.260 、 0.351 、 0.284 、 0.343$ 。 可以看出该断裂带活动性影响面积广、强度 大, 且断裂北西段的活动性较弱于北东段, 但 其与北西向断裂带（F3、F5、F12、F13）交汇 部位为区内构造活动性最强地段。

北西向断裂带主要包括永和圩断裂 F15、 神光山断裂 $\mathrm{F} 14$, 为正断层, 自南东向北西穿 过了 D17、D22、D19、D27，HI 依次为 0.336、 $0.225 、 0.171 、 0.195$ 。可以看出该断裂带南 东端与莲花山深断裂带相交位置为构造活动 性影响较强的地段, 但往北西段却为区内构造 活动性较弱的地段。这是由于 F14、F15 断裂 为新生代断陷盆地兴宁盆地的控盆断层, 盆地 长期处于稳定沉降中, 大量泥沙在此沉积, 形 成地势平坦的洪积、冲积平原, 它并非地貌发 育进入了老年阶段, 而只是构造运动的结果。 由此可见, 采用 $H I$ 对构造沉陷区并不具有地 貌发育阶段划分意义。当然, 正是由于构造活 动显著影响到 $H I$ 值, 这也成为很多学者用其 进行区域构造活动强烈状况的判定依据。

根据对研究区内三组主要的构造线进行 $H I$ 对比, 不难发现, 莲花山断裂带为区内主 要构造系统, 尤其处在与北西向断裂带交汇部 位的梅州市区、蕉岭县、大埔县, 构造活动更 强。这也与地震记录比较吻合, 据记载, 研究 区内地震多集中于上述三处市县，1970 年至 1980 年间共发生 106 次轻微地震 ${ }^{[25]}$, 这也验 证了利用 $H I$ 值可反映构造活动。

\section{5. 结论与讨论}

(1) 面积-高程积分是分析和刻画区域地 貌特征的定量化指标, 基于 DEM 数据和 GIS 空 间分析功能可以对其值进行快速提取, 以分析 和判断区域地貌发育特征及其构造活动性、岩 性抗侵蚀能力及其山地灾害发育强度等特征, 尤其适合华南山区小流域, 地球内外动力活动 强烈, 而研究程度较少的地区, 以面积高程积 分开展其特征及相互作用的研究, 为从整体上 研究地质地貌的空间格局及发育特征提供了 重要理论与方法支撑。

（2）随着河流等级的提高，相应河流流 域的面积逐渐增大, 面积一高程积分值呈现出 一种收玫的态势，高程-面积积分值具有较强 的空间尺度效应，在研究过程中，应该结合研 究目的和研究区地质地貌的实际情况进行分 析尺度的合理选择。本文研究结果显示地貌发 育阶段和特征基本不受尺度影响，几种尺度呈 现一致性趋势; 以 $50 \mathrm{~km}^{2}$ 以下的一级河流为基 本单元所得的 $H I$ 值与地层岩性、灾害发育强 度等空间分布存在空间相对一致性趋势。而随 着流域单元面积的增大, $H I$ 值与岩性和灾害 
的相关性逐渐减弱, 而与区域构造特征的空间 相关性逐渐增强, 流域单元面积为 200- $500 \mathrm{~km}^{2}$, 河流等级为四级时, $H I$ 的结果较 符合区域构造活动特征。

（3）基于面积-高程积分的计算结果表明 广东梅江流域总体上处于流域地貌发育阶段 的壮年期, 根据资料分析和野外调查, 近年来 受全球气候变化等影响, 该区域呈现的水土流 失、崩岗、滑坡、泥石流等频发性特点, 浅层 侵蚀作用主要体现在流水引起的水土流失及 山地灾害对地貌的改造作用, 侵蚀剥蚀作用强 烈, 自然现象和分析结果存在较好的耦合关 系。面积高程积分制也很好地指示了区域内构 造活动性, 研究区主要受三组构造控制, 且莲 花山断裂带为区内主要构造系统, 尤其处在与 北西向断裂带交汇部位的梅州市区、蕉岭县、 大埔县, 构造活动更强。该地区黑云母二长花 岗岩的抗侵蚀力最大, 混合花岗岩次之, 砂岩、 砾岩、砂砾岩以及粉砂岩、泥岩、灰岩的抗侵 蚀最小。这可能反映出所选区域内的侵入岩主 要位于七目嶂山系, 海拔较高、山势陡峭, 剥 蚀以河流机械剥蚀为主, 而沉积岩主要位于地 势较缓的丘陵、平原地区, 剥蚀以化学风化为 主。这可能与该地区域处于高温多雨的气候环 境, 且山高坡陡, 岩石主要以流水侵蚀和河流 机械剥蚀作用为主有关。

(4) 气候变化-浅层侵蚀-地貌过程-构造 活动之间存在复杂的相互作用关系, 只从一个 侧面来反映地貌形态的空间分异, 还不能完揭 示圈层相互作用的内在机理, 结合研究区的地 质环境特征, 对面积高程积分与构造活动、地 貌形成过程、灾害发育等的内在关系有待于进 一步深入研究。

\section{参考文献:}

[1]. 张虎男. 构造地貌研究在广东地震地质工作中的 应用.地震地质,1985,01:59-66.

[2]. 王岸,王国灿.构造地貌及其分析方法述评.地质科 技情报,2005,24(4):7-13.

[3]. 李利波,徐刚,胡健民等. 基于 DEM 的活动构造研 究.中国地质,2012,03:595-604.

[4]. Strahler, A1N1 Hypsometric(Area-Altitude) analysis of erosional topography. Bulletin of the Geological Society of America, 1952, 63:1117 1142.

[5]. 祝士杰,汤国安,李发源等.基于 DEM 的黄土高原 面积高程积分研究.地理学报,2013,07:921-932.
[6]. 赵洪壮,李有利,杨景春等.天山北麓流域面积高度 积分特征及其构造意义.山地学报,2009,27(3): 285-292.

[7]. 艾南山.流域系统的信息熵. 水土保持学报, 1987,1(2):1-8.

[8]. 艾南山,岳天祥.再论流域系统的信息熵.水土保持 学报,1988,2(4):1 9.

[9]. 信忠保,许昫心,马元旭.黄土高原面积高程分析及 其侵蚀地貌学意义. 山地学报,2008,26(3): 356-363.

[10]. 施炜.黄河中游晋陕峡谷的 DEM 流域特征分析及 其新构造意义.第四纪研究,2008,02:288-298.

[11]. 李利波,徐刚,胡健民等. 基于 DEM 的活动构造研 究.中国地质,2012,03:595-604.

[12]. 赵洪壮,李有利,杨景春等.面积高度积分的面积依 赖与空间分布特征. 地理研究,2010,29(2): 271-282.

[13]. 祝士杰.基于 DEM 的黄土高原流域面积高程积分 谱系研究.南京师范大学,2013.

[14]. 廖义善,蔡强国,秦奋等.基于 DEM 黄土丘陵沟壑 区不同尺度流域地貌现状及侵蚀产沙趋势. 山地 学报,2008,03:347-355.

[15]. 姜鲁光,张祖陆.鲁中南山地流域地貌的高程-面积 分析. 山东师范大学学报 (自然科学 版),2003,01:63-66.

[16].王晓朋,潘委,任群智.基于流域系统地貌信息熵的 泥石流危险性定量评价.北京大学学报(自然科学 版),2007,02:211-215

[17].王钧,欧国强,杨顺,季宪军,陆桂红.地貌信息熵在 地震后泥石流危险性评价中的应用. 山地学 报,2013,01:83-91.

[18]. 承继成,江美球.流域地貌数学模型[M]. 北京:科学 出版社,1986:136-146.

[19]. 张敬春,李川,张梅,刘耕年.格尔木河流域面积-高 程积分值的地貌学分析. 山地学 报,2011,03:257-268.

[20]. Strahler A N. Hypsometric (area-altitude) analysis of erosional topography. Bulletin of the Geological Society of America.1952.

[21]. S. H. Brocklehurst, K. X. WHIpple. Hypsometry of glaciated landscapes. Earth Surface Processes and Landforms. 2004.

[22]. Harlin.Watershed morphometry and time to hydrograph peak. Journal of Hydrology.1984.

[23]. 崔灵周.流域降雨侵蚀产沙与地貌形态特征耦合 关系研究.西北农林科技大学.2002.

[24]. Rachel C. Walcott, M. A. Summerfield. Scale dependence of hypsometric integrals: An analysis of southeast African basins. Geomorphology. 2007,(1).

[25]. 广东省地质局.1:20 万梅县幅区域水文地质调查 报告.广东省地质局水文工程地质二大 队,1981.11. 